Jurnal SMART Keperawatan, 2020, 7 (2), 148-152

\title{
HUBUNGAN PERKEMBANGAN ANAK USIA PRASEKOLAH ANTARA IBU BEKERJA DAN TIDAK BEKERJA DI PAUD HJ. SITI ANISAH SEMARANG
}

\author{
Boediarsih, Hendri Dwi Kurniawan, Indah Wulaningsih \\ STIKes Karya Husada Semarang, Jl. Kompol R. Soekanto No.46 Semarang, (024) 6724581 \\ Email :boediarsih@stikesyahoedsmg.ac.id
}

\begin{abstract}
ABSTRAK
Perkembangan anak pada usia prasekolah sebagaigolden agemerupakan perkembangan yang sangat berpengaruh terhadap perkembangan periode berikutnya hingga anak menjadi dewasa yang dipengaruhifaktor internal (faktor ras, keluarga, umur, jenis kelamin, genetic dan kelainan kromosom) dan faktor ekternal (keluarga, gizi, budaya dan teman bermain). Gangguan tumbuh kembang akan menghambat terciptanya sumber daya manusia yang berkualitas sebagai penentu masa depan pembangunan bangsa dan negara. Konsekuensi ibu bekerja merupakan perubahan hidup dalam keluarga juga mengakibatkan pengasuhan dan perawatan anak beralih pada pengasuh baik itu keluarga sendiri atau babysitter.. Tujuan untuk mengetahui hubungan perkembangan anak usiaprasekolah antara ibu bekerja dan tidak bekerja. Metode penelitian kuantitatif dengan desain cross sectional. Populasi yaitu semua ibu yang mempunyai anak usia 3-5 tahun di PAUD HJ Siti Anisah Semarang sejumlah 36 anak. Metode sampling purposive sampling dengan sampel sejumlah 33 anak. Hasil penelitian setelah dilakukan uji statistik uji statistik Chi square menunjukkan nilai $p$ value 0,019 . Kesimpulan : ada hubungan perkembangan anak prasekolah antara ibu bekerja dan tidak bekerja di Paud HJ. Siti Anisah Semarang.
\end{abstract}

Kata kunci : perkembangan anak; ibu bekerja; ibu tidak bekerja

\section{PRE-SCHOOL-AGE CHILDREN'S DEVELOPMENT RELATIONSHIP BETWEEN WORKING MOTHER AND NON-WORKING MOTHER AT HJ. SITI ANISAH PRE-SCHOOL OF SEMARANG}

\begin{abstract}
The development of children at preschool age as the golden age is a development that greatly influences the development of the next period until the child becomes an adult which is influenced by internal factors (factors of race, family, age, gender, genetic and chromosomal disorders) and external factors (family, nutrition, culture). and playmates). Disorders of growth and development will hinder the creation of quality human resources as determinants of the future development of the nation and state. The consequence of working mothers is a change in life in the family as well as resulting in child care and care switching to caregivers, either their own families or babysitters. The aim of the studywas to determine the relationship between the development of preschool aged children between working and non-working mothers. Quantitative research method was used with cross sectional design. The population was all mothers who have children aged 3-5 years in PAUD HJ Siti Anisah Preschool of Semarang with a total of 36 children. The sampling method was purposive sampling with a sample of 33 children. The results of the research after statistical tests were carried out by the Chi square test showed a $p$ value of 0.019 . There is a relationship between the development of preschool children between working and non-working mothers at HJ. Siti Anisah Preschool of Semarang.
\end{abstract}

Key words: child development; working mother; non-working mother

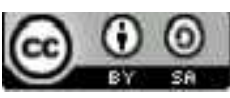

Jurnal SMART Keperawatan is licensed under a Creative Commons Attribution-ShareAlike 4.0 International License 


\section{LATAR BELAKANG}

Perkembangan anak pada usia prasekolah disebut sebagai masa emas "Golden Age" yang artinya perkembangan pada usia ini sangat berpengaruh terhadap perkembangan pada periode berikutnya hingga anak menjadi dewasa(Sulistiani, W. 2016). Usia 0-6 tahun adalah usia yang sangat menentukan dalam pembentukan karakter baik sikap, perilaku, dan kepribadian seorang anak di masa depan (Dorlina,N. 2015). Umumnya pada tahap ini anak usia dini belajar mengenai berbagai hal termasuk dalam mengembangkan kemampuan motorik, kognitif, bahasa, serta sosioemosional mereka (Mayar,F. 2015)Handayani, A. 2015). Data Depkes RI 2017 mencapai 20\% atau setara dengan 0,7 juta balita di Indonesia mengalami gangguan perkembangan yaitu gangguan berkembangan motorik halus maupun gangguan perkembangan motorik kasar, gangguan pendengaran, kecerdasan kurang dan keterlambatan bicara ( Depkes Rl,2017). sedangkan menurut Dinkes 2015 sebesar 75.789 $(55,02 \%)$ anak usia prasekolah mengalami gangguan perkembangan (Kementerian kesehatan,2015).

Ibu bekerja adalah seorang ibu yang bekerja di luar rumah untuk mendapatkan penghasilan di samping membesarkan dan mengurus anak di rumah.Konsekuensi ibu bekerja adalah perubahan hidup dalam keluarga juga mengakibatkan pengasuhan dan perawatan anak beralih pada pengasuh baik itu keluarga sendiri atau babysitter.Sebagian besar waktu ibu habis untuk bekerja, sehingga intensitas pertemuan antara ibu dan anak berkurang, padahal waktu ibu bersama anak dan aktifitas bersama anak sangat penting untuk perkembangan anak secara terarah dan hasil yang optimal (Setyani,F. 2015).Ibu yang tidak bekerja, tentunya memiliki banyak waktu yang dapat dihabiskan bersama anaknya dan mereka juga dapat melatih dan mendidik anak, sehingga perkembangan anak lebih baik..
Berdasarkan studi pendahuluan yang dilakukan pada bulan April tahun 2019 di PAUD Hj. Siti Anisah Semarang, didapatkan hasil bahwa jumlah murid rata-rata ada 36 selama 3 bulan dalam 1 tahun yaitu 18 perempuan dan 18 laki-laki berusia sekitar 3-5 tahun. Ada beberapa kegiatan yang biasa mereka lakukan seperti jalan sehat di sekitar PAUD tersebut, kemudian juga melakukan kerja bakti dan mengaji bersama di setiap hari jumat.Hasil wawancara dengan guru di PAUD Hj. Siti Anisah ada 3 orang anak yang terlihat cukup mandiri dengan menunjukkan perilaku tidak menangis ketika kedua orangtua tidak mendampingi di sekolah, mampu membereskan mainannya dan 7 orang anak terlihat kurang mandiri dengan menunjukkan perilaku mereka yang menginginkan kedua orangtua mendampingi saat di sekolah.Berdasarkan data serta fenomena diatas, dilakukan penelitian untuk mengetahui hubungan perkembangan Anak usia Prasekolah antara Ibu bekerja dan tidak bekerja.

\section{METODE}

Penelitian ini merupakan yang sifatnya deskriptif kuantitatif dengan desain cross sectional. Populasi adalah seluruh ibu dan anak usia prasekolah (3 - 5 tahun) sejumlah 36 anak. Besar sampel dalam penelitian ini di tentukan dengan rumus Slovin didapat sampel 33 anak, dengan teknik sampling yaitu dengan purposive sampling. Analisa penelitian dengan chi square untuk menganalisa hubungan perkembangan anakusia pra sekolah dengan ibu yang bekerja dan ibu yang tidak bekerja. Penelitian ini memiliki nomer etik 1497/KH.KEPT/KT/XI/2019. 


\section{HASIL}

Tabel 1 Distribusi frekuensi perkembangan pada anak usia pra sekolah di PAUD Hj. Siti Anisah Semarang tahun 2020

\begin{tabular}{lll}
\hline Perkembangan anak & Jumlah & Prosentase \\
\hline Sesuai & 22 & 66,67 \\
Meragukan & 11 & 33,33 \\
\hline Total & 33 & 100 \\
\hline
\end{tabular}

Tabel 1 diketahui bahwa perkembangan anak usia prasekolah didapatkan hasil perkembangan anak yang sesuai terdapat 22 anak (66,67\%), dan perkembangan anak dengan hasil meragukan terdapat 11 anak (33,33\%).

Tabel 2 Distribusi frekuensi ibu bekerja dan tidak bekerja yang memiliki anak pra sekolah di PAUD Hj. Siti Anisah Semarang tahun 2020

\begin{tabular}{lll}
\hline Variabel & Jumlah & Prosentase \\
\hline Ibu bekerja & 16 & 48,48 \\
Ibu tidak bekerja & 17 & 51,52 \\
\hline Total & 33 & 100 \\
\hline
\end{tabular}

Tabel 2menunjukkan bahwa ibu bekerja sebanyak $16(48,48 \%)$, dan ibu tidak bekerja sebanyak $17(51,52 \%)$.

Tabel 3 hubungan perkembangan anak usia prasekolah antara ibu bekerja dan tidak bekerja

\begin{tabular}{|c|c|c|c|c|c|c|}
\hline \multirow{3}{*}{ Status ibu } & \multicolumn{4}{|c|}{ Perkembangan anak pra } & \multirow{3}{*}{$\begin{array}{l}\text { Total } \\
\%\end{array}$} & \multirow{3}{*}{$\begin{array}{l}P \\
\text { value }\end{array}$} \\
\hline & \multicolumn{2}{|c|}{ Sesuai } & \multicolumn{2}{|c|}{ Meragukan } & & \\
\hline & $\mathrm{n}$ & $\%$ & $\mathrm{n}$ & $\%$ & & \\
\hline Bekerja & 7 & 43,8 & 9 & 56,2 & 100 & \\
\hline $\begin{array}{l}\text { Tidak } \\
\text { bekerja }\end{array}$ & 15 & 88,2 & 2 & 11,8 & 100 & 0,019 \\
\hline
\end{tabular}

Berdasarkan tabel 3 diketahui bahwa terdapat 16 anak dengan ibu bekerja terdapat 7 anak (43.8\%) memiliki perkembangan dengan hasil sesuai, 9 anak (56.2\%) memiliki perkembangan dengan hasil meragukan, dan terdapat 17 anak dengan ibu tidak bekerja terdapat 15 (88.2\%) anak memiliki perkembangan dengan hasil sesuai, 2 anak (11.8\%) memiliki perkembangan dengan hasil meragukan dengan $p$ value0, 019, yang menyatakan ada hubungan perkembangan anak prasekolah antara ibu bekerja dan ibu tidak bekerja di Paud Hj. Siti Anisah Semarang.

\section{PEMBAHASAN}

Perkembangan anak usia prasekolah pada ibu bekerja dengan menggunakan kuesioner pra skrening perkembangan (KPSP) dan berdasarkan analisis distribusi frekuensi didapatkan hasil perkembangan anak yang sesuai terdapat 22 anak (66,67\%), dan perkembangan anak dengan hasil meragukan terdapat 11 anak (33,33\%). Hal ini sesuai dengan penelitian terdahulu dimana Ibu yang bekerja cenderung kurang dalam memberikan perhatian serta waktu yang cukup untuk beraktifitas maupun memberikan stimulasi yang cukup pada anak sehingga peran pada ibu bekerja dalam kuantitas waktu bersama anak dan melakukan stimulasi pada anak usia prasekolah lebih rendah daripada peran ibu yang tidak bekerja (Sam,A. 2016).

Emmy (1986) perkembangan dapat terpenuhi secara optimal. Namun jika kasih sayang dan perkembangan anak menjadi terganggu akibat intraksi ibu dengan anak sangat terbatas, maka perlu pemikiran lebih mendalam sebelum memutuskan untuk bekerja lbu yang sibuk bekerja seringkali merasa lelah saat pulang dari kantor atau tempat kerja dan ibu sulit menemukan cara-cara kreatif dan berbagi keceriaan bersama anak termasuk di akhir pekan, padahal sesungguhnya ibu dapat melakukan hal-hal kecil bersama anak yang justru memiliki dampak atau manfaat yang luar biasa bagi keeratan hubungan ibu dan anak, misalnya dalam melakukan aktifitas bermain sambil belajar bersama anak dan pada anak yang ditinggal ibunya bekerja hal ini kurang di dapatkan oleh mereka, pada ibu bekerja yang mempunyai anak usia prasekolah mereka kurang memberikan perhatian, kasih sayang, serta stimulasi yang belum optimal sehingga perhatian 
dari orang lain yaitu pengasuh anak selain ibu terutama pada saat anak melakukan aktifitas disaat ibunya pergi bekerja, padahal hal tersebut sangat berpengaruh pada perkembangan anak kedepannya.Perkembangan anak dipengaruhi oleh banyak faktor, salah satu faktor utama adalah keluarga, Pengaruh keluarga adalah pada sikap dan kebiasaan keluarga dalam mengasuh dan mendidik anak, hubungan orang tua dengan anak dan hubungan antara saudara(Sam,A. 2016).

Berdasarkan hasil analisis tersebut menunjukkan bahwa ibu tidak bekerja paling banyak dengan jumlah 51,52\% dan ibu yang bekerja sejumlah 48,48\%. Ibu tidak bekerja dalam melakukan stimulasi pada anak usia prasekolah dapat dilakukan secara seimbang baik dalam motorik, bahasa, maupun sosial dan kemandirian.Ibu yang tidak bekerja memiliki waktu dan melakukan aktifitas yang lebih banyak bersama anak, anak juga bisa mendapatkan perhatian dan kasih sayang yang penuh dari ibu sehingga anak juga bisa mendapatkan kedekatan emosional pada ibu. Sehingga anak cenderungmemperhatikan apa yang dilakukan dan diucapkan oleh ibu, maka ibu juga bisa dengan mudahnya melakukan perannya dalam melakukan stimulasi dan bisa diterapkan oleh anak (Santosa,2016).

Berdasarkan hasil penelitian yang dilakukan di Paud $\mathrm{Hj}$. Siti Anisah Semarang.setelah dialukan uji statistik uji statistik Chi square menunjukkan nilai $p$ value $\leq 0,05$ yaitu 0,019 . Hal ini menunjukkan bahwa terdapat hubungan perkembangan anak prasekolah antara ibu bekerja dan tidak bekerja di Paud Hj. Siti Anisah Semarang. Perkembangan anak pada usia prasekolah disebut sebagai masa emas "Golden Age" yang artinya perkembangan pada usia ini sangat berpengaruh terhadap perkembangan pada periode berikutnya hingga anak menjadi dewasa (Sulistiani,W. 2016). Usia 0-6 tahun adalah usia yang sangat menentukan dalam pembentukan karakter baik sikap, perilaku, dan kepribadian seorang anak di masa depan (Dorlina, N. 2015). Umumnya pada tahap ini anak usia dini belajar mengenai berbagai hal termasuk dalam mengembangkan kemampuan motorik, kognitif, bahasa, serta sosio emosional mereka (Mayar, F. 2015).

Penelitian ini sesuai dengan hasil penelitian Hubungan ibu bekerja dengan perkembangan balita usia 4-5 tahun di TK Dharma Wanita Desa Grogol Kecamatan Tulangan Kabupaten Sidoarjo ( Mutiani, 2017 ) hasil penelitian menunjukkan ada hubungan ibu bekerja dengan perkembangan balita usia 4-5 tahun di TK Dharma Wanita Desa Grogol Kecamatan Tulangan Kabupaten Sidoarjo, dimana dari 35 ibu yang bekerja sebagian besar 24 (68,6\%) mempunyai balita yang meragukan.

Ibu yang bekerja mempunyai waktu lebih sedikit daripada ibu yang tidak bekerja dan menghabiskan waktunya bersama anak 24 jam, namun stimulasi yang diberikan pada anak tidak hanya dengan kuantitas saja melainkan juga kualitas ibu dalam menjalankan perannya untuk memberikan stimulasi pada anak karena itu jauh lebih penting daripada lamanya melakukan aktifitas bersama anak belum tentu diketahui tentang apa yang harus dilakukan saat bersama anak. Ibu yang tidak bekerja mampu menyediakan perhatian yang cukup untuk memberikan stimulasi pada perkembangan anak, pada ibu tidak bekerja juga lebih banyak memberikan waktu dalam mengasuh dan beraktifitas bersama anak.

\section{KESIMPULAN}

Sebagian besar perkembangan anak usia prasekolah sesuai sebesar $66,67 \%$ dan anak dengan perkembangan meragukan sebesar $33,33 \%$. Sedangkan ibu yang tidak bekerja sebesar 51,52\%. Ada hubungan perkembangan anak prasekolah antara ibu bekerja dan tidak bekerja dipaud HJ. Siti Anisah Semarang. Penelitian ini menambah wawasan, pengetahuan, pengalaman dan diharapkan sebagai acuan dalam perkembangan anak usia pada ibu bekerja dan tidak bekerja 
Jurnal SMART Keperawatan, 2020, 7 (2), 148-152

SJKP 2020

DOI: http://dx.doi.org/10.34310/iskp.v7i2.382

pISSN 2301-6221; elSSN 2502-5236

http://stikesyahoedsmg.ac.id/ojs/index.php/sikp

\section{REFERENSI}

Depkes RI. (2017). Pedoman Nasional Tumbuh Kembang Anak. Jakarta: Gramedia.

Dorlina, N. (2015). Perkembangan Bahasa Anak Prasekolah. Jurnal Pembinaan dan Pengembangan Pendidikan.

Handayani, A. (2015). Keseimbangan Kerja Keluarga pada Perempuan Bekerja. Tinjauan Teori Border. Buletin Psikologi, 21(2), 90

Kementrian Kesehatan. (2015). Profil Kesehatan Indonesia Tahun 2010. Jakarta: Kementrian kesehatan.

Mayar, F. (2015). Perkembangan Sosial Anak Usia Dini Sebagai Bibit Untuk Masa Depan Bangsa. Jurnal Al-Ta'lim, Jilid 1, Nomor 6 November 2015, hlm. 459-464

Notoatmodjo, S. (2015). Metodologi Penelitian Kesehatan Edisi Revisi. Jakarta: PT. Rineka Cipta

Sam, A. (2016, Agustus 29). Retrieved September 13, 2019, from pengertian keluarga: http://sobatbaru/pengertiankeluarga.html

Santoso, S. (2016). Kesehatan dan Gizi. Jakarta: Rineka Cipta

Setyani, F. (2015). Hubungan Status Ibu Bekerja Dengan Perkembangan Anak Usia Toddler di RW 03 Kelurahan Depok. Skripsi. Jakarta. Universitas Pembangunan Veteran

Sulistiani, W. (2016). Penerapan Metode Bermain untuk Meningkatkan Kemampuan Sosial Anak Usia Dini. Jurnal IImiah Psikologi dan Psikologi KelautanKemarit 